\title{
PENENTUAN KADAR GULA DARAH SEBELUM DAN SESUDAH PEMBERIAN AIR PERASAN MENGKUDU (Morinda citrifolia Linn) TERHADAP KELINCI (Oryctolagus Cuniculus)
}

\author{
${\text { Hartini } \mathbf{H}^{1^{*}} \text {, Putri Kurnia Sari }}^{2}$ \\ ${ }^{1}$ Akademi Kesehatan John Paul II Pekanbaru \\ ${ }^{2}$ Akademi Analis Kesehatan Fajar Pekanbaru \\ *Email:hartini_h@rocketmail.com
}

\begin{abstract}
ABSTRAK
Umumnya penyakit diabetes mellitus diobati dalam bentuk antidiabetik oral dan injeksi insulin. Namun, pada penelitian yang dilakukan Marles dan Farn Worth tanaman tradisional dapat digunakan untuk pengobatan terhadap diabetes melitus karena memiliki efek samping yang rendah. Salah satu obat tradisional yang dapat menurunkan kadar gula darah adalah tanaman buah mengkudu (Morinda citrifolia Linn). Mengkudu merupakan salah satu alternatif pangan fungsional karena mengandung flavanoid dan saponin pada buah mengkudu terbukti dapat menurunkan kadar gula darah. Penelitian ini bertujuan untuk menentukan air perasan mengkudu untuk menurunkan kadar gula darah. Metode Penelitian ini adalah eksperimental dengan rancangan the post test only control group design. Penelitian ini menggunakan 3 kelompok perlakuan yaitu kontrol negatif, kontrol positif, dan perasan buah mengkudu dosis 50\% selama 14 hari perlakuan. Analisis kadar glukosa darah dilakukan sebanyak 2 kali (pre dan post test). Data dianalisis dengan menggunakan One-Way Anova, post Hoc dan uji t berpasangan. Berdasarkan uji statistik uji one way Anova yang menunjukan bahwa ada perbedaan yang signifikan $(p<0,05)$. Berdasarkan hasil penelitian menunjukan bahwa air perasan buah mengkudu (Morinda citrifolia L) mampu menurunkan kadar gula darah sebesar $176 \mathrm{mg} / \mathrm{dL}$ dibandingkan dengan obat antidiabetik metformin (Kontrol Positif).
\end{abstract}

Kata kunci : Diabetes mellitus, buah mengkudu

\begin{abstract}
Generally, diabetes mellitus was healed in the oral antidiabetic and insulin injection forms. But, based on on the research of Marles and Farn Worth in 1996 showed that the traditional plant could be used to heal through diabetes mellitus because the low sideeffect. Noni (Morinda citrifolia L) is one of the functional food alternative because it contains flavanoid, saponin that able to reduce blood sugar levels. This research aimed to consider the noni (Morinda citrifolia L) juice which was able to reduce the blood sugar levels. This research method was experimental by pre test and post test design. This research used 3 groups such as negative control, positive control and noni juice with dosing of $50 \%$ for 14 days of threatment. Analysis of the blood glucose levels were operated as many as 2 times (pre and post test). The data was analyzed by using One-Way Anova, post Hoc and couple t-test. Based on the statistic test by one way Anova test which showed that there was the significant difference $(p<0,05)$. Based on the research results showed that the noni (Morinda citrifolia L) juice was able to reduce the blood sugar levels about $176 \mathrm{mg} / \mathrm{dL}$ than antidiabetic metformin (positive control).
\end{abstract}

Keywords : Diabetes mellitus, Noni 


\section{PENDAHULUAN}

Berbagai upaya yang telah dilakukan untuk mengobati dan mencegah terjadinya diabetes mellitus, saat ini masyarakat banyak menggunakan tanaman tradisional karena memiliki efek samping yang rendah (Zhang, dkk., 2008). Tanaman merupakan sumber kekayaan alam yang potensi di Indonesia. Salah satu manfaat yang diambil dari tananam adalah khasiat sebagai obat dari bagian tanaman seperti daun, bunga, biji atau buah, kulit pohon dan akar (Gholib, 2009).

Obat tradisional memiliki beragam kelebihan yaitu mudah diperoleh, ekonomis, bahkan umumnya gratis karena dapat ditanam sendiri. Oleh karena itu, obat tradisional diharapkan mampu berperan dalam usaha pencegahan dan pengobatan penyakit berdasarkan bukti ilmiah. Beberapa tanaman yang biasa digunakan sebagai obat diabetes mellitus adalah biji alpukat, mahkota dewa, buah naga, jambu biji, pare, dan tanaman seledri. Salah satu obat tradisional yang dapat menurunkan kadar gula darah adalah tanaman buah mengkudu (Morinda citrifolia Linn) (Dalimartha, 2005).

Mengkudu merupakan buah yang memiliki fungsi konstruktif bagi penderita diabetes, yaitu membangun kembali jaringan-jaringan yang rusak, menyembuhkan penyakit komplikasi lain, menurunkan kadar gula darah (Kirtishanti, dkk., 2008).

Berdasarkan penelitian yang dilakukan oleh Nayak, dkk., (2010) kandungan flavanoid, saponin pada buah mengkudu terbukti dapat menurunkan kadar gula darah. Saponin bekerja dalam menghambat pengosongan lambung. Saponin juga dapat mengurangi absorpsi nutrisi yang masuk ke darah sehingga kadar gula darah berubah. Salah satu faktor kelemahan buah mengkudu adalah aroma dan rasanya yang menyengat sehingga masyarakat enggan untuk mengkonsumsinya (Hardoko, dkk., 2003). Aroma yang kurang sedap ini dapat disiasati dengan cara merebus untuk mengurangi aroma yang tidak sedap, tetapi dengan cara merebus dapat mengurangi senyawa yang ada dalam mengudu (Yang, 2010).

Selama ini masyarakat mengonsumsi mengkudu dengan cara mengestraksinya yaitu dengan merebus lalu diminum atau dengan memblendernya sehingga didapatkan ekstrak berupa jus. Meskipun mengandung senyawa yang bermanfaat bagi kesehatan, pangan fungsional tidak berbentuk kapsul, tablet atau bubuk yang berasal dari senyawa alami (Badan Pengawasan Obat dan Makanan, 2001). Produk minuman fungsional yang beredar di pasaran tersedia 
dalam berbagai bentuk, seperti jus (sari buah), serbuk minuman cepat larut (serbuk instan), serta dalam bentuk teh herbal (teh celup) mengkudu (Winarti, 2005).

Berdasarkan uraian diatas, maka peneliti tertarik untuk melakukan penelitian dengan judul Penentuan Kadar Gula Darah Sebelum dan Sesudah Pemberian Air Perasan Buah Mengkudu (Morinda citrifolia Linn) Terhadap Kelinci (Oryctolagus cuniculus).

TINJAUAN TEORI

Morfologi buah mengkudu
Mengkudu tumbuh di daratan rendah pada ketinggian $1500 \mathrm{~m}$. Tinggi pohon mengkudu mencapai 3-8 $\mathrm{m}$, memiliki bunga bongkol berwarna putih. Buahnya berwarna hijau mengkilap dan memiliki totol-totol, dan ketika sudah tua berwarna putih dengan bintik-bintik hitam (Hasdianah, 2012). Spesies mengkudu, Morinda citrifolia L adalah spesies yang paling dikenal oleh masyarakat Indonesia karena penyebarannya yang luas. Morinda citrifolia L dibedakan menjadi 2 varietas, yaitu Morinda citrifolia var citrifolia dan Morinda citrifolia var braceata (Dewi, 2012).

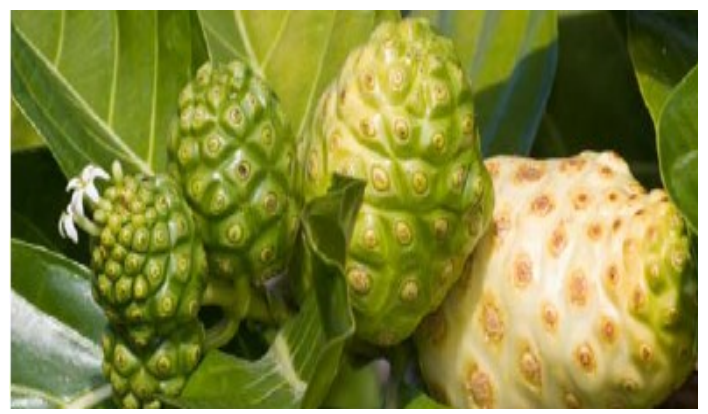

(Sumber: Nelson, S.C. 2006. Species Profiles for Pacific Island Agroforestry/ http://agroforestry.org/images/pdfs/Morinda-noni.pdf)

\section{Kandungan kimia buah mengkudu}

Buah mengkudu memiliki kandungan senyawa metabolit sekunder yang bermanfaat bagi kesehatan, di samping kandungan nutrisinya yang beragam seperti vitamin $\mathrm{A}, \mathrm{C}$, niasin, tiamin, dan riboflavin serta mineral yang terdapat pada mengkudu merupakan antioksidan yang hebat seperti zat besi, kalsium, natrium, dan kalium (Winarti, 2005). Buah mengkudu mengandung asam askorbat dengan kadar yang cukup tinggi. Kandungan tersebut memiliki fungsi sebagai antioksidan yang dapat menetralisasi radikal bebas, yaitu partikel berbahaya yang dapat merusak materi gentika dan merusak sistem kekebalan tubuh. Selain asam askorbat, buah 
mengkudu juga memiliki kandungan asam kaproat dan asam kaprilat yang menyebabkan bau busuk yang tajam (Dewi, 2012).

Buah mengkudu efektif dalam membantu mengurangi gejala penyakit artritis, penyakit jantung, hepatitis, sakit kepala dan otot, hipertensi, diabetes mellitus, gastritis, arteriosklerosis, demam, influenza, dan kanker (Wang,dkk., 2002).

\section{Diabetes mellitus}

Menurut Dalimartha (2007), diabetes mellitus merupakan sekumpulan gejala yang timbul pada seseorang yang ditandai dengan kadar glukosa darah melebihi nilai normal akibat tubuh kekurangan insulin. Gejala klinis yang khas dari diabetes mellitus yaitu banyak makan, banyak minum dan banyak kencing. Disamping dengan keluhan sering kesemutan terutama pada jari-jari tangan, badan terasa lemas, berat badan menurun drastis, gatal-gatal, terjadi gangguan mata, dan bila ada luka sukar sembuh, ini merupakan gejala klasik yang umum terjadi pada penderita diabetes mellitus (Rismayanthi, 2011).

Beberapa gejala yang sering dikeluhkan oleh penderita diabetes mellitus antara lain rasa haus, rasa lapar, sering kencing, berat badan turun, badan terasa lemas, gatal, kesemutan, pandangan kabur, serta kulit kering. Gejala lain yang mungkin dikeluhkan penderita diabetes mellitus antara lain kejang pada kaki atau betis karena akibat kekurangan cairan dan elektrolit. Komplikasi yang dapat ditimbulkan kerena pengaruh diabates mellitus antara lain adanya gangguan pembuluh darah (Dalimartha, 2012).

Diagnosis diabetes mellitus berdasarkan pemeriksaan kadar glukosa darah, bukan karena adanya glukosa di urin (glukosuria). Diagonosis diabetes mellitus dapat dipastikan apabila hasil pemeriksaan kadar glukosa darah sewaktu $\geq 200 \mathrm{mg} / \mathrm{dL}$ dan hasil pemeriksaan kadar glukosa darah puasa $\geq 126 \mathrm{mg} / \mathrm{dL}$.

Pada penatalaksanaan diabetes mellitus, langkah pertama yang harus dilakukan adalah penatalaksanaan tanpa obat berupa pengaturan diet dan olah raga. Apabila dalam langkah pertama ini tujuan penatalaksanaan belum tercapai, dapat dikombinasi dengan langkah farmakologis berupa terapi insulin atau terapi obat hipoglikemik oral, atau kombinasi keduanya (Dirjen Bina Farmasi, dkk., 2005).

\section{Kelinci}

Kelinci merupan hewan percobaan yang paling sering digunakan setelah mencit dan tikus. Kelinci telah digunakan dalam hampir semua cakupan biomedis. Keuntungan penggunaan kelinci sebagai hewan percobaan adalah memungkinkan 
adanya pengulangan penelitian dan mudah diatur. Sedangkan kerugian dari penggunaan kelinci ini rentan terhadap berbagai penyakit. Menurut Research Animal Resources (2000), kadar glukosa darah normal kelinci adalah 75-150 mg/dL. Sedangkan menurut Keeble (2001) kadar glukosadarah normal pada kelinci berkisaran antara 4,2-10,4 $\mathrm{mmol} / \mathrm{L}(76,36-$ $189,09 \mathrm{mg} / \mathrm{dL})$. Kadar glukosa darah ini dapat meningkat akibat adanya stres, shock, atau cara mengendalikan hewan yang tidak benar. Maka dai itu hindari pengukuran kadar glukosa darah dalam keadaan stres (Keeble, 2001).

\section{METODE PENELITIAN}

\section{Jenis dan Desain Penelitian}

Jenis penelitian ini adalah eksperimen dengan desain penelitian pre test dan post tes, yaitu mengukur pengaruh perlakuan sebelum dan sesudah pada kelompok eksperimen dengan membandingkan kelompok tersebut dengan kelompok kontrol.

\section{Waktu Dan Tempat Penelitian}

Penelitian ini dilaksanakan pada bulan Mei 2016 di Laboratorium Laboratorium Akademi Analis Kesehatan Yayasan Fajar Pekanbaru.

\section{Sampel penelitian}

Sampel yang digunakan adalah kelompok populasi yang memenuhi kriteria inklusi dan eksklusi.

a. kriteria inklusi : Kelinci sehat, jenis kelamin jantan, umur 6-12 bulan dan berat badan $1,5-2 \mathrm{~kg}$.

b. Kriteria eksklusi : Kelinci yang sakit, cacat, mati, umur $<6$ bulan dan berat badan $<1,5 \mathrm{~kg}$.

Menurut Research Animal Resources (2000), kadar glukosa darah normal kelinci adalah 75-150 mg/dL. Sedangkan menurut Keeble (2001) kadar glukosa darah normal pada kelinci berkisaran antara 4,2-10,4 $\mathrm{mmol} / \mathrm{L}(76,36-189,09 \mathrm{mg} / \mathrm{dL})$

\section{Alat dan Bahan}

Alat yang diguanakn antara lain Glukometer, kain penyaring, spuit, kapas alkohol, beaker glass, lanset. Bahan yang digunakan pada penelitian ini yaitu, darah kelinci, aquadest, metformin, gula tebu, mengkudu.

\section{Prosedur Kerja}

\section{Persiapan Hewan Uji}

Hewan percobaan yang digunakan yaitu kelinci. Hewan ini sebelumnya telah diadaptasi selama seminggu. Selama adaptasi berat badan kelinci ditimbang dan prilakunya diperhatikan. Kelinci dianggap sehat apabila perubahan berat badan tidak lebih dari $10 \%$ serta memperlihatkan prilaku yang normal sebelum diperiksa kadar glukosanya, kelinci dipuasakan selama lebih dari 12 jam. 


\section{Persiapan air perasan mengkudu}

Buah mengkudu yang telah mateng dicuci dengan air mengalir, dibersihkan dari kulit kemudian dagingnya ditimbang dengan berat yang dikehendaki. Lalu diperas dengan kain penyaring.

\section{Pemberian glukosa pada kelinci}

Gula tebu dilarutkan sedikit demi sedikit dalam air panas hingga $100 \mathrm{~mL}$. Dosis glukosa yang digunakan yaitu $7,35 \mathrm{gr} / \mathrm{kg}$ BBKelinci yang dilarutkan dalam $100 \mathrm{~mL}$ air. Diberikan kepada kelinci secara oral melalui mulut.

\section{Pemberian air perasan mengkudu pada}

\section{kelinci}

Air perasan mengkudu konsentrasi 50\% diberikan pada kelinci dengan dosis sebagai berikut :

Kelinci $\mathrm{I}=9,8 \mathrm{~mL} / 1,5 \mathrm{~kg}$ BB kelinci

Kelinci II $=10,4 \mathrm{~mL} / 1,6 \mathrm{~kg}$ BB kelinci

Kelinci III $=10,4 \mathrm{~mL} / 1,6 \mathrm{~kg}$ BB kelinci

Diberikan selama 7 hari pada kelinci secara oral melalui mulut. Setelah 7 hari berturut-turut kelinci diberi minum jus buah mengkudu, diperiksa kadar gula darahnya.

\section{Pemeriksaan kadar glukosa darah pada kelinci}

Siapkan semua alat dan bahan untuk pengambilan darah pada kuping telinga kelinci. Bersihkan telinga kelinci dengan alkohol 70\%. Tusuk dengan lanset. Setelah darah keluar, darah pertama dihapus dan darah selanjutnya diteteskan pada sebuah strip yang telah dimasukkan kedalam celah gluko Dr. Kemudian tunggu beberapa saat hingga keluar hasil kadar glukosa darah.

\section{Analisis Data}

Data diolah dengan menggunakan SPSS 17, selanjutnya analisa data dilakukan dengan uji T. Hasil analisis data ditampilkan dalam bentuk grafik dan tabel.

\section{HASIL DAN PEMBAHASAN}

\section{Hasil}

Pada hasil penelitian yang telah dilakukan tentang penentuan kadar gula darah sebelum dan sesudah perlakuan khususnya pemberian air perasan buah mengkudu (Morinda citrifolia L.) terhadap kelinci yang terdapat pada Tabel 1.

Tabel 1. Distribusi Hasil Kadar Gula Darah Pada Kelinci Sebelum dan Sesudah Pemberian Air Perasan Buah Mengkudu (Morinda citrifolia L.)

\begin{tabular}{cccccc}
\hline \multirow{2}{*}{ Perlakuan } & \multicolumn{2}{c}{ Rata-Rata Kadar Gula Darah $(\mathrm{mg} / \mathrm{dL})$} & Rata-Rata Penurunan \\
\cline { 2 - 3 } & $\begin{array}{c}\text { Sebelum } \\
\text { Induksi } \\
\text { Glukosa }\end{array}$ & $\begin{array}{c}\text { Setelah } \\
\text { Induksi } \\
\text { Glukosa }\end{array}$ & $\begin{array}{c}\text { Setelah } \\
\text { Perlakuan }\end{array}$ & $\begin{array}{c}\text { Persentase Penurunan Kadar } \\
\text { (mg/dL) }\end{array}$ & $\begin{array}{c}\text { Gula Darah (\%) yang } \\
\text { dibandingkan dengan } \\
\text { Kontrol Positif }\end{array}$ \\
\hline P1 & 73 & 276 & 244 & 32 & $18,19 \%$ \\
P2 & 78 & 303 & 79 & 224 & $100 \%$ \\
P3 & 88,7 & 288 & 112 & 176 & $78,58 \%$ \\
\hline
\end{tabular}

Keterangan :

P1 : Kontrol Negatif (Aquadest)

P2 : Kontrol Positif (Metformin)

P3 : Perasan Buah Mengkudu 
Berdasarkan Tabel 1 menunjukkan bahwa rata-rata penurunan kadar gula darah $(\mathrm{mg} / \mathrm{dL})$ dari yang tertinggi ke terendah yaitu kelompok P3 sebesar 224 mg/dL, kelompok P2 176 (mg/dL) dan P1 sebesar $32(\mathrm{mg} / \mathrm{dL})$. Penurunan kadar gula darah antara kelompok P3 terhadap P2 memberikan persentase penurunan sebesar $78,58 \%$ sedangkan penurunan kadar gula darah antar kelompok P1 terhadap P2 memberikan persentase penurunan sebesar $18,19 \%$.

Tabel 2. Perbandingan Kadar Gula Darah Pada Kelinci Sebelum dan Sesudah Pemberian Air Perasan Buah Mengkudu (Morinda citrifolia L.)

\begin{tabular}{lccc}
\hline \multicolumn{1}{c}{ Kelompok } & $\begin{array}{c}\text { Rata-rata Kadar Gula } \\
\text { Darah } \pm \text { SD }(\mathrm{mg} / \mathrm{dL})\end{array}$ & $\begin{array}{c}\text { Selisih Rata-rata Kadar } \\
\text { Gula Darah } \pm \text { SD (mg/dL) }\end{array}$ & Nilai p \\
\hline $\begin{array}{l}\text { Kelompok P1 (Kontrol negatif) } \\
\text { Sebelum (pre test) }\end{array}$ & $168,33 \pm 6,02$ & & 0,014 \\
$\begin{array}{l}\text { Sesudah (post test) } \\
\text { Kelompok P2 (Kontrol Positif) }\end{array}$ & $162,67 \pm 6,02$ & $5,667 \pm 1,154$ & \\
Sebelum (pre test) & $246,00 \pm 29,51$ & & 0,004 \\
Sesudah (post test) & $235,33 \pm 28,50$ & $10,667 \pm 1,154$ & \\
Kelompok P3 (Perasan Buah Mengkudu) & & & 0,004 \\
Sebelum (pre test) & $228,33 \pm 7,57$ & $9,000 \pm 1,000$ & \\
Sesudah (post test) & $219,33 \pm 6,65$ & & \\
\hline
\end{tabular}

Berdasarkan analisis uji $t$ kadar gula darah kelompok P1, P2, dan P3 mengalami penurunan. Hasil rata-rata pemeriksaan kadar gula darah pre test kelompok P1 adalah 168,33 $\pm 6,02 \mathrm{mg} / \mathrm{dL}$,

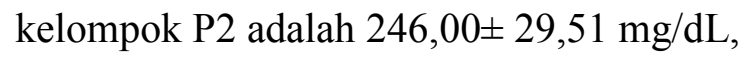
kelompok P3 adalah 228,33 \pm 7,57 mg/dL, sedangkan kadar gula darah post test kelompok P1 adalah 162,67 $\pm 6,02 \mathrm{mg} / \mathrm{dL}$, kelompok P2 adalah 235,33 $\pm 28,50 \mathrm{mg} / \mathrm{dL}$, dan kelompok P3 adalah 219,33 \pm 6,65 $\mathrm{mg} / \mathrm{dL}$. Peneliti menggunakan uji t untuk menentukan perbedaan kadargula darah pre test dan post test data kelompok P1, $\mathrm{P} 2$, dan P3. Berdasarkan analisis uji $\mathrm{t}$ dengan tingkat kemaknaan $\mathrm{p}<0,05$, yang artinya ada pengaruh pemberian air perasan buah mengkudu (Morinda citrifolia L.) sebelum dan sesudah perlakuan terhadap kadar gula darah pada kelinci.

\section{Pembahasan}

Pada penelitian ini menggunakan kelinci yang dibagi 3 kelompok perlakuan, yaitu kelompok kontrol negatif, kelompok kontrol positif dan perlakuan yang sama menggunakan air perasan buah mengkudu dengan konsentrasi $\quad 50 \%$. Rata-rata penurunan pada kontrol negatif sebesar 32 $\mathrm{mg} / \mathrm{dL}$, sedangkan kontrol positif rata-rata penurunan sebesar $224 \mathrm{mg} / \mathrm{dL}$ dan pada perlakuan rata-rata penurunan kadar gula darah sebesar $176 \mathrm{mg} / \mathrm{dL}$.

Kelompok yang menggunakan kontrol negatif (air) menunjukkan adanya 
penurunan kadar gula darah sebesar 32 mg/dL. Meminum air putih sebanyak 8 gelas dalam sehari dapat melindungi seseorang dari kadar gula darah yang tinggi sebesar $21 \%$ dibandingkan seseorang yang sedikit mengkonsumsi air putih. Konsumsi air putih membantu proses pembuangan semua racun didalam tubuh, termasuk gula berlebihan. Dengan meminum air putih menyebabkan terjadinya pemecahan gula.Untuk membantu mengeluarkan zat-zat kimia seperti glukosa (James, 2010).

Kelompok kontrol positif (Obat metformin) menunjukkan adanya penurunan kadar gula darah sebanyak 224 $\mathrm{mg} / \mathrm{dL}$. Metformin bekerja dengan cara menurunkan kadar gula darah melalui sel target yang ada dihati, otot, dan lemak. Obat metformin juga bekerja dengan menurunkan kadar gula darah dengan menurunkan glukoneogenesis dihati sehingga akan menurunkan kadar gula darah puasa. Metformin juga mempunyai efek lain yaitu menurunkan kadar trigliserida plasma, kolesterol LDL, verylow density lipoprotein (VLDL) (Srinivasan, dkk., 2006 ).

Kelompok yang menggunakan air perasan buah mengkudu konsentrasi 50\% menunjukkan adanya penurunan kadar gula darah $176 \mathrm{mg} / \mathrm{dL} \quad(78,58 \%)$ dibandingkan dengan kontrol positif (obat antidiabetik metformin). Hasil ini sesuai dengan penelitian yang membuktikan bahwa pemberian ekstrak atau air buah mengkudu dapat menurunkan kadar gula darah kelinci yang diinduksi glukosa. Buah mengkudu mengandung flavanoid, saponin pada buah mengkudu terbukti dapat menurunkan kadar gula darah. Senyawa yang terdapat dalam buah mengkudu yaitu zat proxeronin dan prexeroninase yang berfungsi untuk mengendalikan kadar gula darah (Sjabana, dkk., 2002).

\section{KESIMPULAN DAN SARAN}

\section{Kesimpulan}

Berdasarkan hasil penelitian ini dapat disimpulkan bahwa pemberian air perasan buah mengkudu (Morinda citrifolia L.) $50 \%$ dapat menurunkan kadar glukosa darah kelinci sebesar $176 \mathrm{mg} / \mathrm{dL}$.

\section{Saran}

Perlu dilakukan penelitian lebih lanjut dengan penentuan konsentrasi yang optimum untuk menurunkan kadar gula darah. 


\section{DAFTAR PUSTAKA}

Badan Pengawasan Obat dan Makanan. 2001. Kajian proses standarisasi produk pangan fungsional di Badan Pengawasan Obat dan Makanan. Lokakarya. Kajian Penyusunan Standar Pangan Fungsional. BadanPengawasan Obat dan Makanan, Jakarta

Dewi, N. 2012. Budidaya, Khasiat dan Cara Olah Mengkudu UntukMengobati Berbagai Penyakit

Ditjen Bina Farmasi., Alkes, 2005. Pharmaceutical Care Untuk Penyakit Diabetes Mellitus. Departemen Kesehatan RI. Jakarta

Hardoko, A. Parhusip., I.P. Kusuma. 2003.Mempelajari karakteristik sari buahmengkudu (Morinda citrifolia Linn.) yang dihasilkan melalui fermentasi. Jurnal Teknologi Industri Pertanian XIV(2): 144-153

Hasdianah, 2012. Mengenal diabetes mellitus pada orang dewasa dan anakanak dengan solusi herbal. Yogyakarta, Nuha Medika

James, 2010.Who drinking water is beneficial in treating diabetes and depression. Hal: 7:26

Kirtishanti, Aguslina, Ryanto Budiono, Ratih., Fitria Isfandiari. 2008. Efek Ekstrak Daun Mengkudu (Morinda citrifolia L.) Terhadap Jumlah Protein
GLUT4 pada Tikus Putih Hiperglikemik.Jurnal Farmasi Indonesia Vol. 4 No.2 Hal 55-62.

Nayak, B. Shivananda, Julien R. Marshall, Godwin Isitor, Andrew Adogwa. 2010. Hypoglicemic and Hepatoprotective Activity of Fermented Fruit Juice of Morinda citrifolia (Noni) in Diabetic Rats.Complementary and Alternativemedicine volume 2011, Article ID 875293.

Rismayanthi, C., 2011. Terapi Insulin Sebagai Alternatif Pengobatan Bagi Penderita Diabetes.

Srivanas S, Ambles GR, Baur LA, Garnett SP, Tepsa M, Yap F, dkk. Randomized controlled trial of metformin for obesity and insulin in children and adolescents improvement in body composition and fasting insulin. $\mathrm{J}$ clin Endocrinol Metab 2006 : 91 : 2074-80. Wang. M.y., B.J. Brest, C.J. Jensen, D. Nowicki, C. Su, A.K. Palu, and G. Andersen. (2002). Morinda Citrifolia (Noni) : A literature review and recent advances In noni research.

Winarti, C. 2005. Peluang Pengembangan Buah Mengkudu (Morindacitrifolia L). Jurnal Litbang Pertanian. 24 (4) : 149155.

Yang, J. 2010. Make Fresh Noni (Morinda citrifolia) Juice at home fromhttp://www.wptrc.org/userfiles/file /Yang/Nonifinal.pdf 